\title{
An Observational Real-Life Study with a New Infant Formula in Infants with Functional Gastro-Intestinal Disorders
}

\author{
Yvan Vandenplas ${ }^{1, *(D)}$, Laetitia Gerlier ${ }^{2}$, Karin Caekelbergh ${ }^{2}$, Nan-Study-Group ${ }^{\dagger}$ and Mike Possner $^{3}$ \\ 1 KidZ Health Castle, Vrije Universiteit Brussel (VUB), UZ Brussel, 1090 Brussels, Belgium \\ 2 IQVIA, 1930 Zaventem, Belgium; Laetitia.Gerlier@iqvia.com (L.G.); Karin.Caekelbergh@iqvia.com (K.C.) \\ 3 Nestlé Nutrition Institute, 60528 Frankfurt am Main, Germany; Mike.Possner@de.nestle.com \\ * Correspondence: yvan.vandenplas@uzbrussel.be; Tel.: +32-475748794 \\ + Membership of the Nan-Study-Group is provided in the Acknowledgments.
}

Citation: Vandenplas, Y.; Gerlier, L.; Caekelbergh, K.; Nan-Study-Group; Possner, M. An Observational Real-Life Study with a New Infant Formula in Infants with Functional Gastro-Intestinal Disorders. Nutrients 2021, 13, 3336. https://doi.org/ $10.3390 /$ nu13103336

Academic Editor: Nadja Haiden

Received: 22 August 2021

Accepted: 18 September 2021

Published: 23 September 2021

Publisher's Note: MDPI stays neutral with regard to jurisdictional claims in published maps and institutional affiliations.

Copyright: () 2021 by the authors. Licensee MDPI, Basel, Switzerland. This article is an open access article distributed under the terms and conditions of the Creative Commons Attribution (CC BY) license (https:// creativecommons.org/licenses/by/ $4.0 /)$.

\begin{abstract}
Functional gastro-intestinal disorders (FGIDs) impair the quality of life of many infants and their families. A formula with partial whey hydrolysate, starch, high magnesium content, prebiotic fructo-oligosaccharide and galacto-oligosaccharide and the probiotic Lactobacillus reuteri DSM 17938 was given during two weeks to 196 infants with at least two FGIDs. The efficacy was evaluated with the Cow Milk-associated Symptom Score $\left(\right.$ CoMiSS $\left.^{\circledR}\right)$ and quality of life with the QUALIN score. The formula was shown to decrease FGIDs within three days (decrease of CoMiSS -1.29 (3.15) (mean (SD), $p<0.0001$ ) followed by an improvement of quality of life after seven days (increase QUALIN +1.4 (7.8); $p$ : 0.008). Constipation decreased from $18.8 \%$ to $6.5 \%$ within three days. In combination with reassurance and guidance, the nutritional intervention was shown to be effective in infants with FGIDS in real-life circumstances.
\end{abstract}

Keywords: constipation; colic; CoMiSS; crying; functional gastro-intestinal disorder; gastro-esophageal reflux; regurgitation; QUALIN; quality of life

\section{Introduction}

Functional gastro-intestinal disorders (FGIDs) occur in more than $25 \%$ of all infants and are a frequent reason for parents to consult a health care provider [1-4]. Regurgitation, infantile colic and functional constipation are the most common FGIDs [1-4]. Although FGIDs have per definition no identifiable underlying organic cause [5], infants with a FGID and their families display a reduced quality of life (QoL) and consult more often than asymptomatic controls [6]. FGIDs are a frequent reason for hospitalization, parental anxiety and depression, loss of parental working days with relevant social consequences and/or administration of drugs [2,7]. Many infants present with a combination of several FGIDs, although the reported range varies from $4.2 \%$ to $77 \%[1-3,8]$.

Anticipatory guidance, reassurance and helping caregivers to cope with the infant's symptoms and providing support for the infant-family interaction is the cornerstone of the management of FGIDs. However, the majority of parents expect "more": they expect the health care provider to "do" something and to deliver a prescription. The spiral of increasing prescriptions of proton pump inhibitors and other medications testifies to this reality [8,9]. Therefore, nutritional treatment is an attractive option since it is safe, devoid of adverse effects and supported by evidence of benefit [10].

The aim of this open real-life observational intervention study was to evaluate in infants presenting with a least two FGIDs the efficacy of an infant formula containing five components for which there is evidence of benefit from randomized controlled trials: partial whey hydrolysate (pHF-W), Limosilactobacillus (L.) reuteri DSM 17938, a prebiotic mixture of galacto-oligosaccharides (GOS) and fructo-oligosaccharides (FOS), high magnesium and potato starch. 


\section{Materials and Methods}

The study design was a prospective, multicenter, observational study over 14 days with the study formula (Table 1: composition of study formula) in full formula-fed infants 0-4 months old presenting with at least two FGIDs out of regurgitation, constipation and crying.

Table 1. Composition of study formula per $100 \mathrm{~mL}$.

\begin{tabular}{cc}
\hline Energy & $67 \mathrm{kcal}$ \\
\hline Lipid (DHA/ARA) & $3.4 \mathrm{~g}(17 \mathrm{mg} / 17 \mathrm{mg})$ \\
\hline Carbohydrates (lactose/starch) & $7.5 \mathrm{~g}(5.0 \mathrm{~g} / 2.2 \mathrm{~g})$ \\
\hline Fibers (Starch/FOS/GOS) & $0.48 \mathrm{~g}(0.08 \mathrm{~g} / 0.04 \mathrm{~g} / 0.36 \mathrm{~g})$ \\
\hline Potato starch & $2.2 \mathrm{~g}$ \\
\hline Protein (pHF-W) & $1.3 \mathrm{~g}$ \\
\hline Magnesium & $8.37 \mathrm{mg}$
\end{tabular}

Legend: DHA: docosahexaenoic acid; ARA: arachidonic acid; FOS: fructo-oligosaccharide; GOS: galactooligosaccharide; pHF-W: whey partial hydrolysate.

Eighty-two pediatricians agreed to participate in the study. The parents of potential eligible infants were invited to participate in the study by the pediatrician. Enrollment was proposed when the parents consulted because of FGID symptoms. In order to limit selection bias, all consecutive infants fulfilling eligibility criteria for whom the parents provided consent were included.

Inclusion was Day 0; on Day 3 and 7 parents filled in a diary, and the closing visit was planned on Day $14+2$. The trial was approved by the Ethical Committee of the UZ Brussel (B.U.N. 143202042971). Both parents signed the informed consent.

Since this was a real-world observational trial, infants did not have to fulfill Rome IV criteria to be eligible for inclusion. The Cow Milk-associated Symptom Score (CoMiSS ${ }^{\circledR}$; Table 2) was used to quantify the severity of the symptoms. The CoMiSS was developed as a symptom score to quantify the symptoms in a trial comparing the efficacy of two extensive hydrolysates in infants suspected to suffer cow's milk protein allergy (CMPA [11,12]. The CoMiSS ranges from 0 to 33 .

Table 2. The Cow's Milk-associated Symptom Score $\left(\right.$ CoMiSS $\left.^{\circledR}\right)$ value [12].

\begin{tabular}{|c|c|c|}
\hline Symptom & Score & \\
\hline Crying & $\begin{array}{l}0 \\
1 \\
2 \\
3 \\
4 \\
5 \\
6\end{array}$ & $\begin{array}{l}\leq 1 \mathrm{~h} / \text { day } \\
1 \text { to } 1.5 \mathrm{~h} / \text { day } \\
1.5 \text { to } 2 \mathrm{~h} / \text { day } \\
2 \text { to } 3 \mathrm{~h} / \text { day } \\
3 \text { to } 4 \mathrm{~h} / \text { day } \\
4 \text { to } 5 \mathrm{~h} / \text { day } \\
\geq 5 \mathrm{~h} / \text { day }\end{array}$ \\
\hline Regurgitation & $\begin{array}{l}0 \\
1 \\
2 \\
3 \\
4 \\
5 \\
6\end{array}$ & $\begin{array}{l}0 \text { to } 2 \text { episodes / day } \\
\geq 3 \text { to } \leq 5 \text { episodes of small volume } \\
>5 \text { episodes of }>1 \text { coffee spoon } \\
>5 \text { episodes of } \pm \text { half of the feedings in }<\text { half of the feedings } \\
\text { continuous regurgitations of small volumes }>30 \text { min after each feeding } \\
\text { regurgitation of half to complete volume of a feeding in at least half of } \\
\text { the feedings } \\
\text { regurgitation of the complete volume after each feeding }\end{array}$ \\
\hline $\begin{array}{l}\text { Stools } \\
\text { (Bristol scale) }\end{array}$ & $\begin{array}{l}4 \\
0 \\
2 \\
4 \\
6\end{array}$ & $\begin{array}{l}\text { type } 1 \text { and } 2 \text { (hard stools) } \\
\text { type } 3 \text { and } 4 \text { (normal stools) } \\
\text { type } 5 \text { (soft stool) } \\
\text { type } 6 \text { (liquid stool, if unrelated to infection) } \\
\text { type } 7 \text { (watery stools) }\end{array}$ \\
\hline $\begin{array}{l}\text { Skin } \\
\text { symptoms }\end{array}$ & 0 to 6 & $\begin{array}{lc}\text { Atopic eczema } & \text { Head-neck-trunk } \\
\text { Absent } & 0 \\
\text { Mild } & 1 \\
\text { Moderate } & 2 \\
\text { Severe } & 3\end{array}$ \\
\hline
\end{tabular}


Table 2. Cont.

\begin{tabular}{lcl}
\hline Symptom & Score & \\
\hline & 0 to 6 & Urticaria $(0:$ no, $6:$ yes $)$ \\
\hline & 0 & no respiratory symptoms \\
Respiratory & 1 & slight symptoms \\
symptoms & 2 & mild symptoms \\
& 3 & severe symptoms \\
\hline
\end{tabular}

Inclusion criterion was that the sum of the CoMiSS score for minimum two symptoms out of the three symptoms—crying, regurgitation, stools—needed to be $>4$, since 4 was reported to be the median value in presumed healthy infants [13]. Exclusion criteria were any food supplement except vitamins at inclusion, any previous use of a food for special medical purpose, current treatment with laxatives or antibiotics, suspected cow's milk allergy. In other words: the study population consisted of presumed healthy formula-fed infants, except for the presenting manifestations of FGIDs, which were the reasons of the consultation. If the infant was included, the intervention consisted of 14 days exclusive feeding with the test formula.

QoL was evaluated with the QUALIN questionnaire [14]. This questionnaire was specially developed for use in infants and toddlers. The questionnaire includes 34 items with 6 possible answers, scored from -2 (quite false) to +2 (entirely true). The six possible answers were: false, mostly false, true and false, mostly true, true and do not know. The overall score ranges from -68 (poor QoL) and +68 (excellent QoL). Four topics are addressed: behavior and communication, ability to remain alone, family environment, and psychological and somatic well-being.

The primary endpoint was alleviation of symptoms according to the evolution of the CoMiSS and improvement of quality of life (QoL). Statistical analysis was done with SAS version 9.4 (SAS Institute Inc., Cary, NC, USA). Statistical significance was set at a level of 0.05. Standard deviation and interquartile ranges are reported for descriptive statistics. ANOVA and Student $t$-test were used to compare means of independent continuous variables, and when valid, a parametric paired Student $t$-test or a non-parametric Wilcoxon test was used to analyze changes from baseline in continuous outcomes between Day 0 and 14 . The normality of the QUALIN and CoMiSS scores was assessed through the Shapiro-Wilk Test. Normality was assumed if the associated $p$-value of the test statistic was $>0.05$. Multivariate mixed effect model analyses were planned to assess change from baseline score over time (repeated measures). Multivariate mixed effect model was accommodated withinsubject (patient in this case) non-independence or within-unit clustering (physician in this case) and unobserved heterogeneity, at once and allowed for subject-specific conclusions. This was controlled by introducing a random effect (patient) in the model [15]. Time (visit day 1 , home report day 3 , home report day 7 , visit day 14) was also included as a discrete variable and fixed effect since the main interest was the change in mean scores [16]. Other covariates or factors (i.e., age, sex, BMI, gestational age, birth BMI, presence of adverse events, history of allergy, mode of delivery, number of siblings, baseline CoMiSS, baseline QUALIN, type of FGID at baseline) were also included in the model as fixed effects. The inclusion of baseline score as a covariate can help to decrease variability in random errors and increase the probability of detecting the significant time effect on the mean change from baseline in score [16]. Different models were constructed starting from the full model from which covariates are removed sequentially. The selection of the best model was based on the Akaike Information Criterion (AIC). The model with the lowest AIC was selected for the multivariate analysis. The normality of the QUALIN and CoMiSS scores was visually assessed through frequency distributions showing the spread of the scores. Normality was assumed if the distribution was bell-shaped and symmetric around the mean. Quantile-quantile (Q-Q) plots were constructed to assess whether the choice of the distribution was acceptable. Dots perfectly aligned with the straight line mean perfect choice of distribution. The "proc glimmix" procedure in SAS was used for the multivariate mixed effect model analyses in which a Gamma distribution and log link function was 
selected to model non-normal responses, otherwise a normal distribution was specified. Standard errors and two-sided $95 \%$ confidence intervals (CIs) are reported for the covariate estimates of the multivariate analyses (see Supplementary Materials).

Secondary endpoints were the evolution of CoMiSS and QUALIN by subcategory, dietary changes, medications administered and adverse events. Analyses were reported for the full analysis set (FAS).

\section{Results}

Between May and December 2020, 196 infants were included by 51 (of the 82 who agreed to participate) pediatricians (number of inclusions/pediatrician: mean: 3.8; median: 2.0; Q1-Q3: (2.0-4.0). All data were available on Day 14 for 171 infants (87\%). Reasons for the $13 \%$ missing data: not completed 3.6\% (some data missing); lost in follow-up 3.6\%; formula stopped: $5.6 \%$ (day 3: $\mathrm{n}=1$; day 7: $\mathrm{n}=7$; day 14: $\mathrm{n}=3$ ) (patient characteristics: Table 3). At baseline, all infants were full formula fed, but $92(46.9 \%)$ of the infants had been breastfed during a short time (mean: 29.8 days; median: 21.0 days). The sum of the prevalence of the FGIDs was $218 \%$, indicating that all included infants presented with at least two FGIDs and $18 \%$ with a combination of all three (crying, regurgitation, stool problems). Only a minority of infants had received drug treatment prior to inclusion: antibiotics $(2.0 \%)$, antifungals $(1.5 \%)$, acid blocking drugs $(1.0 \%)$, analgesics $(0.5 \%)$ and "OTC" products for digestive problems (3.6\%). Atopic dermatitis was reported in 18 infants $(9.2 \%)$ and the presence of respiratory symptoms in $30(15.3 \%)$, indicating that the impact of these symptoms on the total CoMiSS was minimal.

Table 3. Patient characteristics.

\begin{tabular}{ccc}
\hline Number of infants & (boys\%/girls\%) & $196(55.6 / 44.4)$ \\
\hline Birthweight (gram) & Mean (SD) & $3321(534)$ \\
\hline Gestational age (weeks) & Median (Q1-Q3) & $3320(3020-3685)$ \\
\hline Mode of delivery & Mean (SD) & $38.7(1.6)$ \\
\hline Family history of atopic disease & Vedian (Q1-Q3) & $39(38-40)$ \\
\hline & Cesarean section (\%) & 76.0 \\
\hline Age (months) & At baseline & 24.0 \\
\hline Weight (gram) & Mean (SD) & $1.5(1.0)$ \\
\hline & Median (Q1-Q3) & $1.1(0.7-2.1)$ \\
\hline Estimated overfeeding & Mean (SD) & $4558(1120)$ \\
\hline Feeding & Median (Q1-Q3) & $4225(3780-5175)$ \\
\hline FGID & Yes/No (\%) & $4.6 / 95.4$ \\
\hline & Intact protein (n, \%) & $138(70.4)$ \\
\hline & Partial hydrolysate (n, \%) & $58(29.6)$ \\
\hline Crying (n, \%) & $158(80.6)$ \\
\hline & Regurgitation (n, \%) & $118(60.2)$ \\
\hline & Hard stools (type 1-2) & $36(18.8 \%)$ \\
\hline & Liquid stools (type 6, 7) & $48.5 \%)$ \\
\hline
\end{tabular}

Legend: SD: standard deviation: Q: quartile; FGID: functional gastro-intestinal disorder.

The primary outcome, the evolution of the global CoMiSS, showed a statistically significant decrease of the CoMISS as soon as from Day 3 onwards, which was confirmed at Day 7 and 14 (Table 4). The mean decrease of baseline CoMiSS was 34\%. Table 5 shows the evolution of the relevant symptoms in the CoMiSS and confirms that the scores for 
respiratory symptoms and skin manifestations were low (0.18, CoMiSS range $0-3 ; 0.20$, CoMiSS range $0-12$, respectively). The CoMiSS for stool consistency did not change because soft and fluid stools score, respectively, 2 and 4 , while hard stools also score 4 (CoMiSS range $0-6$ ). Therefore, Table 6 provides more detailed information on the evolution of stool consistency. Table 7 summarizes the change in CoMiSS in the subgroup with a CoMiSS $>9$ $(\mathrm{n}=44)$. Overall, efficacy of the dietary intervention was not different in the group with CoMiSS $\leq 9$ and $>9$.

Table 4. The evolution of global CoMiSS.

\begin{tabular}{ccccc}
\hline & \multicolumn{1}{c}{ Day 3 } & Day 7 & Day 14 \\
\hline $\mathrm{N}$ & 196 & 189 & 182 & 178 \\
\hline Valid (n; \%) & $192(98.0 \%)$ & $186(98.4 \%)$ & $177(97.3 \%)$ & $172(96.6 \%)$ \\
\hline \multicolumn{5}{c}{ CoMiSS $^{\circ}$} \\
\hline Mean (SD) & $6.46(3.09)$ & $5.21(2.90)$ & $4.98(2.93)$ & $4.92(3.06)$ \\
\hline Median (Q1-Q3) & $6(4 ; 8)$ & $5(3 ; 7)$ & $5(3 ; 6)$ & $5(3 ; 6.5)$ \\
\hline Min-Max & $0-15$ & $0-16$ & $0-16$ & $0-16$ \\
\hline Mean (SD) & & $-1.29(3.15)$ & $-1.56(3.47)$ & $-1.53(3.68)$ \\
\hline$p$ & $<$ Change in CoMiSS & $<.0001 *$ & $<0.0001 *$ & $<0.0001 *$ \\
\hline Median (Q1-Q3) & $-1(-3 ; 1)$ & $-2(-4 ; 0)$ & $-1(-3.5 ; 7)$ \\
\hline Min-Max & $-13 ; 10$ & $-13 ; 9$ & $-14 ; 7$ \\
\hline Missing n (\%) & $3(1.6 \%)$ & $5(2.8 \%)$ & $6(3.4 \%)$ \\
\hline Min-Max & $-24 ; 19$ & $-31 ; 24$ & $-18 ; 25$ \\
\hline Missing n (\%) & & $3(1.6 \%)$ & $5(2.8 \%)$ & $7(3.9 \%)$ \\
\hline
\end{tabular}

Legend. $n$ : number; ${ }^{\circ}$ : change is related to baseline; SD: standard deviation; Q: quartile; $p$-value ${ }^{*}$ Wilcoxon test for skewed variables; Min: minimal; Max: maximal.

Table 5. Evolution of specific CoMiSS per time point.

\begin{tabular}{ccccc}
\hline Symptoms & Baseline & Day 3 & Day 7 & Day 14 \\
\hline $\mathrm{n}$ & 196 & 189 & 182 & 178 \\
\hline Crying & 2.24 & 1.72 & 1.29 & 1.23 \\
\hline Regurgitation & 1.31 & 0.76 & 0.75 & 0.72 \\
\hline Stools ${ }^{\circ}$ & 2.53 & 2.44 & 2.64 & 2.59 \\
\hline Skin symptoms & 0.20 & 0.13 & 0.10 & 0.15 \\
\hline $\begin{array}{c}\text { Respiratory } \\
\text { symptoms }\end{array}$ & 0.18 & 0.17 & 0.20 & 0.25 \\
\hline Total CoMiSS & 6.46 & 5.21 & 4.98 & 4.92
\end{tabular}

Legend: n: number; ${ }^{\circ}$ : CoMiSS uses the Bristol stool scale to describe stool consistency; both liquid and hard stools score high.

Table 6. Evolution of CoMiSS per time point for stool consistency.

\begin{tabular}{ccccc}
\hline Stool Type & Baseline & Day 3 & Day 7 & Day 14 \\
\hline $\mathrm{n}$ & 196 & 189 & 182 & 178 \\
\hline 1 and 2 (Hard) & $36(18.8 \%)$ & $12(6.5 \%)$ & $10(5.7 \%)$ & $4(2.2 \%)$ \\
\hline 3 and 4 (Normal) & $40(20.8 \%)$ & $41(22.0 \%)$ & $34(19.2 \%)$ & $31(17.4 \%)$ \\
\hline 5 (Soft) & $68(35.4 \%)$ & $69(37.1 \%)$ & $58(32.8 \%)$ & $65(36.5 \%)$ \\
\hline 6 (Fluid) & $41(21.4 \%)$ & $58(31.2 \%)$ & $69(39.0 \%)$ & $66(37.1 \%)$ \\
\hline
\end{tabular}


Table 6. Cont.

\begin{tabular}{ccccc}
\hline Stool Type & Baseline & Day 3 & Day 7 & Day 14 \\
\hline $\begin{array}{c}\text { 3-6 (nl for } \\
\text { infants) }\end{array}$ & $149(76.0 \%)$ & $168(88.9 \%)$ & $162(89.0 \%)$ & $162(91.0 \%)$ \\
\hline 7 (Watery) & $7(3.7 \%)$ & $6(3.2 \%)$ & $6(3.3 \%)$ & $6(3.4 \%)$ \\
\hline Missing & $4(2.0 \%)$ & $3(1.6 \%)$ & $5(2.7 \%)$ & $6(3.4 \%)$ \\
\hline
\end{tabular}

Legend: n: number; nl: normal.

Table 7. The evolution of CoMiSS in the subgroup with CoMiSS $>9$.

\begin{tabular}{|c|c|c|c|c|}
\hline & & Day 3 & Day 7 & Day 14 \\
\hline \multicolumn{5}{|l|}{$\mathrm{N}$} \\
\hline Valid (n; \%) & 43 & $42(97.7 \%)$ & $40(97.6 \%)$ & $38(95.0 \%)$ \\
\hline \multicolumn{5}{|c|}{ Change in CoMiSS from baseline } \\
\hline Mean (SD) & & $-3.86(3.22)$ & $-4.40(3.69)$ & $-4.55(4.58)$ \\
\hline$p$ & & $<0.0001^{*}$ & $<0.0001^{*}$ & $<0.0001 *$ \\
\hline Median (Q1-Q3) & & $-4(-6 ;-2)$ & $-5(-6 ;-2)$ & $-5(-8 ;-1)$ \\
\hline Min-Max & & $-13 ; 4$ & $-13 ; 3$ & $-14 ; 5$ \\
\hline Missing n (\%) & & $3(1.6 \%)$ & $5(2.8 \%)$ & $6(3.4 \%)$ \\
\hline Min-Max & & $-24 ; 19$ & $-31 ; 24$ & $-18 ; 25$ \\
\hline Missing n (\%) & & $1(2.3 \%)$ & $1(2.4 \%)$ & $2(5.0 \%)$ \\
\hline Total CoMiSS & 10.73 & 6.93 & 6.43 & 6.11 \\
\hline Crying & 3.43 & 2.31 & 1.73 & 1.97 \\
\hline Regurgitation & 2.73 & 1.43 & 1.40 & 1.16 \\
\hline Stools & 3.77 & 2.76 & 2.85 & 2.42 \\
\hline $\begin{array}{l}\text { Skin + resp } \\
\text { symptoms }\end{array}$ & 0.80 & 0.43 & 0.46 & 0.56 \\
\hline
\end{tabular}

Legend: $\mathrm{n}$ : number; SD: standard deviation; Q: quartile; $p$-value * Student's paired $t$-test for normally distributed variables; Min: minimal; Max: maximal; resp: respiratory.

At Day 3, improvement of QUALIN was not yet significant $(p=0.065)$, but the change was significant from Day 7 onwards and continued to improve over time (Table 8).

Table 8. Evolution of the QUALIN score per time point.

\begin{tabular}{ccccc}
\hline QUALIN & Baseline & Day 3 & Day 7 & Day 14 \\
\hline $\mathrm{n}$ & 191 & 186 & 177 & 171 \\
\hline Mean (SD) & $22.7(9.1)$ & $23.6(8.5)$ & $24.0(9.3)$ & $25.8(8.5)$ \\
\hline Median (Q1-Q3) & $22(18 ; 27)$ & $24(16 ; 30)$ & $23(18 ; 30)$ & $25(19 ; 32)$ \\
\hline Min-Max & $(-1 ; 63)$ & $(3 ; 42)$ & $(-8 ; 52)$ & $(8 ; 50)$ \\
\hline Missing & $5(2.6 \%)$ & $3(1.6 \%)$ & $5(2.8 \%)$ & $7(3.9 \%)$ \\
\hline Change from baseline & & $1.0(7.0)$ & $1.4(7.8)$ & $3.2(8.2)$ \\
\hline$p$ & & $0.065 *$ & $0.008^{* *}$ & $<0.0001^{*}$ \\
\hline QUALIN topic & & & 8.90 & 10.33 \\
\hline Behavior/communication & 7.27 & 8.34 & 3.26 & 3.10 \\
\hline Ability to remain alone & 3.58 & 3.24 & 6.70 & 6.93 \\
\hline Family environment & 6.20 & 6.48 & -3.89 & -3.93
\end{tabular}


Table 8. Cont.

\begin{tabular}{ccccc}
\hline QUALIN & Baseline & Day 3 & Day 7 & Day 14 \\
\hline Other & 7.85 & 8.58 & 9.02 & 9.34 \\
\hline Total QUALIN score & 22.71 & 23.58 & 23.99 & 25.77 \\
\hline $\begin{array}{c}\text { Total QUALIN score in subgroup } \\
\text { with CoMiSS }>9\end{array}$ & 22.48 & 23.33 & 25.30 & 26.27 \\
\hline
\end{tabular}

Legend: n: number; SD: standard deviation; Q: quartile; Min: minimal; Max: maximal. * Student's paired $t$-test for normally distributed variables; ${ }^{* *}$ Wilcoxon test for skewed variables.

Regarding CoMiSS, a multivariate analysis using a gamma distribution and log link function with the covariates CoMiSS baseline, age at inclusion, sex, weight at birth and inclusion, gestational age, mode of delivery, adverse events, duration symptoms showed that three factors were significantly and independently associated with the CoMiSS: baseline CoMiSS $(p<0.0001)$, mode of delivery $(p=0.012)$ and duration of symptoms $(p=0.005)$. Regarding QUALIN, the multivariate analysis using a normal distribution and the same covariates as for CoMiSS adding crying, showed that the following factors were significantly and independently associated: baseline QUALIN $(p<0.0001)$, age at baseline $(p=0.0008)$, weight al baseline $(p=0.0413)$ and duration of symptoms $(p<0.0001)$. The estimates of the covariates and diagnostic plots for CoMiSS and QUALIN scores can be found in the Supplementary Materials (see Tables S1 and S2, Figures S1-S4).

During the two-week study period, gastro-intestinal drugs (alginate or proton pump inhibitors) were prescribed to 30 infants. The CoMiSS at baseline did not differ in the subgroups with or without GI drugs: 6.42 vs. 6.60, respectively. No differences in QUALIN were observed: in the subgroup without GI drugs, the evolution of QUALIN was from 22.67 to 25.80 (+3.11) and in the subgroup with GI medications, QUALIN increased from 23.90 to 26.25 (+3.18). In the subgroup not receiving GI drugs, the mean (SD) and median (Q1-Q3) change in CoMiSS over the study period was -1.54 (3.56) $(p<0.0001$ to baseline) and $-5(-8 ;-1)$, respectively. The change in the subgroup receiving GI drugs was smaller: $-1.64(4.29)(p=0.05)$ and $-1(-3.5 ; 0.5)$, respectively.

\section{Discussion}

This open interventional trial with a new therapeutic "comfort" formula containing pHF-W, GOS and FOS, the probiotic $L$ reuteri DSM 17938, a high content of magnesium and starch was shown to decrease infant crying, regurgitation and constipation within three days (according to CoMiSS), subsequently increasing quality of life (according to QUALIN score). The rapid improvement of FGIDs in infants in these real-world study conditions is key in the management of FGIDs since improvement of symptoms will reassure parents.

The CoMiSS was developed as a symptom score in infants suspected to suffer cow's milk protein allergy (CMPA) and was subsequently positioned as an awareness tool for CMPA [11,12]. The P95 cutoff in a healthy population was shown to be $>9$ [13]. Since regurgitation, infant distress, crying and stool consistency are, in combination with respiratory symptoms, atopic dermatitis and urticarial, the constituents of the CoMiSS, CoMiSS was used to show that respiratory and skin symptoms were virtually absent in this study population. The evolution of CoMiSS would then be used to show the evolution of the symptoms during the study intervention. The CoMiSS used the Bristol stool scale to describe stool consistency. Soft stools, type 5 according to Bristol, what is a normal consistency for infants, are accorded 2 points in the CoMiSS (Table 1). Furthermore, Bristol Type 6 (fluid stools) are normal in infants. Therefore, the contribution of the CoMiSS to describe the evolution of stool consistency is misleading. However, if interest is focused on the Bristol Type 1 and 2 (hard stools), a significant improvement of stool consistency could be demonstrated. It may be better to replace the Bristol stool scale by the Brussels Infant and Toddler Stool Scale in the CoMiSS [17]. The multivariate analysis showed that cesarean section and duration of symptoms were risk factors for the level of CoMiSS. Administration of GI drugs was not dependent on the level of CoMiSS or QUALIN (CoMiSS and QUALIN were slightly higher in the group without medication); neither was the evolution of both 
scores different in the groups with and without medication (the difference tended even to be slightly smaller in the group with medication). All these data confirm that GI drugs are not indicated in the management of FGIDs [10].

QUALIN score was independent of CoMiSS (< or $>9$ ), suggesting that at baseline QoL is more dependent on tolerance and bearing capacity of the caregivers than on severity of symptoms. However, when symptoms decreased, QUALIN increased (QoL improved). Thus, QoL is related to symptom severity but the impact of symptoms of QoL at baseline is subject to subjective interpretation.

According to literature data, it can be estimated that about $50 \%$ of infants present with a combination of FGIDs (range 4-77\%) [1-3,8]. It might be difficult for the health care provider to discover the triggering mechanism. Therefore, a dietary approach with different components for which there is evidence for benefit from literature is an attractive approach. Moreover, dietary treatment is safe. At baseline, 29/196 (14.8\%) infants were receiving a formula with the same protein content (pHF-W) as the test formula, but with standard magnesium content, without starch, without prebiotics or L. reuteri.

RCTs have previously shown efficacy for each of the specific ingredients: $p H F-W$, GOS and FOS, a high content of magnesium and starch. FOS and GOS are well-studied prebiotics in infant feeding. FOS and GOS have been known for the past 20 years to stimulate the growth of lactobacilli and bifidobacteria and to decrease possible pathogens in the GI microbiome [18-22].

GOS and FOS have additional benefits outside the management of FGIDs, such as protection for intestinal and extra-intestinal infections [23,24], resulting in decreased secretory IgA levels [25]. GOS and FOS offer also a possible indirect protection for allergy because of inducing a beneficial immunoglobulin profile in infants at high risk for allergy [26].

The pHF-W has been approved by the European Food Safety Association (EFSA) as a protein source suitable to be used in every infant $[27,28]$. A formula with a pHF-W protein is known to be nutritionally adequate [29,30]. pHF-W formulas are well accepted and tolerated [31]. The CoMiSS was developed as an awareness tool to consider a possible diagnosis of CMPA [12], and a cutoff $>9$ was proposed to select a group of infants at risk to suffer CMPA [13]. In this study, 43/196 (21.9\%) of the included infants had a CoMiSS $>9$. However, the consulted pediatrician did not consider the diagnosis of CMPA in these infants, since suspicion of CMPA was an exclusion criterion and since pHF-W is not recommended in the management of CMPA [32]. However, it might be that some of the infants may suffer CMPA, since pHF-W protein does have some efficacy in the management of CMPA. In mice, pHF-W sensitization did not induce whey-induced clinical symptoms, even though sensitization was established [33]. Increased regulatory cell populations in the systemic immune system and a prevention of increased total Th1 and activated Th17 in the intestinal immune organs could contribute to the suppression of allergic symptoms [33]. An Italian study showed that $64 \%$ of infants with a positive double-blind challenge test with intact cow milk protein did tolerate a pHF-W formula [34]. A Japanese study showed oral tolerance in 1-9-year-old children with mild to moderate IgE-mediated CMA that $20 \mathrm{~mL}$ of cow milk was tolerated by $2 / 25,20 \mathrm{~mL}$ of pHF-W by $16 / 25$ and $20 \mathrm{~mL}$ of EHF by $22 / 25$ [35]. These findings suggest that although pHF-W cannot be recommended in the management of CMPA, improvement or even disappearance of symptoms with a pHF-W does not exclude CMPA as a possible diagnosis. The question arises more and more of how to separate FGIDs from non-IgE-mediated mild to moderate CMPA in some infants, since symptoms and management do overlap. Could it just be considered as different wordings for the same condition?

This test formula does have a reduced lactose content $(5.0 \mathrm{~g} / 100 \mathrm{~mL})$. Lactose is an important carbohydrate as it is the predominant carbohydrate in mother's milk, which enhances the development of a GI microbiome rich in lactobacilli and bifidobacteria [36]. Lactose in infant formula improves calcium absorption [37]. However, a formula without lactose content has been shown to result in a clinically significant decrease of FGIDs [38,39]. 
Therefore, a reduced content of lactose may offer the balance between advantages and disadvantages of lactose.

\subsection{Constipation: A Role for Magnesium, pHF-W, GOS and FOS}

Magnesium-rich formula as a single change in the composition of infant formula was shown to be effective in the management of infant constipation, increasing the frequency and decreasing the hardness of the stools $[40,41]$. Compounds such as magnesium citrate work by pulling water into the intestines. The decrease in hardness of the stools is related to an increased water content [42]. Softer stools and increased frequency were directly related to a decrease of painful defecation, and thus decreased crying time [41]. An open trial with a pHF-W, GOS, Bifidobacterium lactis and high magnesium was reported to be effective in the management of constipation and improved many QoL aspects, such as sleep and work-related QoL, parent-child relationship, better social interaction with friends and relatives, resulting in a daily and overall improved QoL [43]. The test formula contains $12.49 \mathrm{mg}$ magnesium per $100 \mathrm{kcal}(8.37 \mathrm{mg} / 100 \mathrm{~mL})$, which is about $50 \%$ more than the amount in a regular starter formula $(8.5 \mathrm{mg} / 100 \mathrm{kcal})$. The European Delegated Act, EU DA 2016/127, recommends 5-15 mg/100 kcal.

There is evidence from RCTs that a formula with FOS and GOS, a pHF-W and starch is effective in the management of constipation and colic [44,45]. Defecation frequency in infants fed a pHF-W is almost twice the frequency of infants fed intact protein [46]. The prebiotic scGOS/lcFOS formulas have positive effects on stool characteristics such as stool consistency and stool frequency [47]. A formula with FOS and GOS, pHF-W and starch but also with the addition of a high concentration sn-2 palmitic acid resulted in a strong tendency of softer stools in constipated infants, but not in a difference in defecation frequency [48]. In an RCT, comparing a casein-dominant starter formula to a whey-predominant formula, with long-chain poly-unsaturated fatty acids and FOS and GOS, hard stools ( 0.7 vs. $7.5 \%, p<0.001$ ) were decreased with the test formula [49]. In comparison to the control group, the test group's stool microbiota composition, gastric and intestinal transit times were closer to that of the breast-fed group [49].

The probiotic added to the test formula, L. reuteri DSM 17938, was also shown to reduce constipation in infants [50].

\subsection{Colic: FOS and GOS, L. reuteri}

The GI microbiome of infants presenting with colic is characterized by decreased numbers of lactobacilli and bifidobacteria, and more proteobacteria, including species producing gas and inflammation [51]. Since the FOS and GOS added to the test formula have been shown to stimulate the growth of a bifidogenic microbiome, the prebiotics could be beneficial in treating infant colic $[44,45]$. A fermented formula with FOS and GOS was shown to decrease colic [52].

The probiotic added to the test formula, L. reuteri DSM 17938, has been shown to be effective in the management of colic and several meta-analyses recommended its use in this indication $[53,54]$.

\subsection{Regurgitation: $p H F$, Probiotics and Starch}

Carob bean gum and starch from corn and rice are the best studied thickeners and did not show a clinically relevant difference in efficacy [55]. The efficacy of potato starch to thicken infant formula has not been well studied, but potato starch is well known as a very effective thickener of soups and gravies. The gastric emptying of a pHF-W is comparable to that of mother's milk and significantly faster than that of intact milk protein [56] L. reuteri was shown to reduce regurgitation and to enhance gastric emptying [57]. Different studies showed a significant effect on regurgitation within one week of dietary treatment [58-60].

Limitations of an open real-life intervention study is that bias and a placebo effect cannot be ruled out. A placebo effect may explain the negative outcome of two studies evaluating the effect of L. reuteri DSM 17983 on infantile colic [61,62], while meta-analyses 
conclude for efficacy of the same strain in colic $[53,54]$. In future studies, the microbiome composition should be assessed in this kind of intervention trial, and epigenetic effects should be evaluated following formula administration [63,64]. Epigenetics involves several mechanisms including DNA methylation, histone modifications and microRNAs, which can modify the expression of genes [64]. The period between conception, pregnancy and the two first years of life is considered the optimal time for environmental factors, such as nutrition, to exert their beneficial epigenetic effects [64]. Up to now, insufficient attention has been accorded to on how early feeding may have an impact on functional (immunological as well as epigenetic) activity and on establishing epigenetic markers of immunological responses to milk [65]. It would be of interest to prolong the observation period in future studies, in order to evaluate whether these short-term beneficial effects have an ongoing positive effect later in life, and, e.g., decrease irritable bowel syndrome or recurrent abdominal pain in older children.

\section{Conclusions}

These data confirm that reassurance, guidance and nutritional treatment are an effective intervention in the management of FGIDs in infants. A real-life observational study cannot exclude a placebo effect of the dietary intervention, but most important is that symptoms decreased and QoL improved. Since nutritional treatment is safe, it offers the possibility to health care providers to improve the QoL of families with infants with FGIDs without risk of adverse effects.

Supplementary Materials: The following are available online at https:/ /www.mdpi.com/article/ 10.3390/nu13103336/s1, Table S1: CoMiSS score—Multivariate analysis, Table S2: QUALIN scoreMultivariate analysis, Figure S1: Q-Q Plot for CoMiSS, Figure S2: Distribution of CoMiSS scores, Figure S3: Q-Q Plot for QUALIN, Figure S4: Distribution of QUALIN scores.

Author Contributions: Y.V.: concept, analysis data, writing manuscript; L.G.: statistical analysis; K.C.: data collection, data management; Nan-Study-group: inclusion of patients; M.P.: concept, resources, supervision, co-writing. All authors have read and agreed to the published version of the manuscript.

Funding: This research was funded by NIN EMENA.

Institutional Review Board Statement: The trial was approved by the Ethical Committee of the UZ Brussel (B.U.N. 143202042971).

Informed Consent Statement: Both parents signed the informed consent.

Data Availability Statement: No extra data available.

Acknowledgments: Nan-Study-Group: Hélène André, Samuel Balbeur, Nadine Balduck, Claude Brumagne, Vincent Cassart, Elsa Chevalier, Guenaelle Dauphin, Anja De Coene, Daniela De Coster, Veerle De Ketelaere, Linde De Keyzer, Laura Delobelle, Dominique Denil, Christine De Montpellier, Sybille De Montpellier, Thierry Devreker, Bogdan Dima, Marie-Sophie Feytons, Joke Gorissen, MarieAgnès Hayez, Olivia Jadot, Soheila Javadian, Sabine Jespers, Mélanie Léonard, Angélique L'homme Boris Limme, Philip Maes, Michel Maka, Frédéric Motte, Katrien Naudts, Caroline Oosterlynck, Liliane Palumbo, Aagje Pareyn, Annie Paternoster, Emilie Poitoux, Julie Poskin, Delphine Santens, Virginie Schellekens, Lieve Sevenants, Grace Tan, Kaatje Van Aerschot, Kristel Vandenbosch, Nathalie Van der Aa, Désirée Van Doorn, Nathalie Van Hoorebeek, Kristien Van Laer, Bart Van Lierde, Katrien Vanneste, Astrid Verbist, Wim Vergauwen, Inge Van Wambeke, Wendy Werckx. IQVIA did the statistical analysis.

Conflicts of Interest: Y.V. has participated as a clinical investigator, and/or advisory board member, and/or consultant, and/or speaker for Abbott Nutrition, Ausnutria, Biogaia, By Heart, CHR Hansen, Danone, ELSE Nutrition, Friesland Campina, Nestlé Health Science, Nestlé Nutrition Institute, Nutricia, Mead Johnson Nutrition, Phathom Pharmaceuticals, United Pharmaceuticals (Novalac), Yakult, Wyeth. Laetitia Gerlier and Karin Caekelbergh are employees of IQVIA; IQVIA received consulting fees from Nestlé. Mike Possner is a Nestlé employee. 


\section{References}

1. Steutel, N.F.; Zeevenhooven, J.; Scarpato, E.; Vandenplas, Y.; Tabbers, M.M.; Staiano, A.; Benninga, M.A. Prevalence of functional gastrointestinal disorders in European infants and toddlers. J. Pediatr. 2020, 221, 107-114. [CrossRef] [PubMed]

2. Bellaiche, M.; Ategbo, S.; Krumholz, F.; Ludwig, T.; Miqdady, M.; Abkari, A.; Vandenplas, Y. A large-scale study to describe the prevalence, characteristics and management of functional gastrointestinal disorders in African infants. Acta Paediatr. 2020, 109, 2366-2373. [CrossRef] [PubMed]

3. Beser, O.F.; Cullu Cokugras, F.; Dogan, G.; Akgun, O.; Elevli, M.; Yilmazbas, P.; Ocal, M.; Bayrak, N.A.; Sezer Yamanel, R.G.; Bozaykut, A.; et al. The frequency of and factors affecting functional gastrointestinal disorders in infants that presented to tertiary care hospitals. Eur. J. Pediatr. 2021, 180, 2443-2452. [CrossRef]

4. Vandenplas, Y.; Hauser, B.; Salvatore, S. Functional gastrointestinal disorders in infancy: Impact on the health of the infant and family. Pediatr. Gastroenterol. Hepatol. Nutr. 2019, 22, 207-216. [CrossRef] [PubMed]

5. Benninga, M.A.; Faure, C.; Hyman, P.E.; St. James Roberts, I.; Schechter, N.L.; Nurko, S. Childhood functional gastrointestinal disorders: Neonate/Toddler. Gastroenterology 2016, 15, 1443-1455. [CrossRef]

6. Zeevenhooven, J.; Koppen, I.J.; Benninga, M.A. The new Rome IV criteria for functional gastrointestinal disorders in infants and toddlers. Pediatr. Gastroenterol. Hepatol. Nutr. 2017, 20, 1-13. [CrossRef] [PubMed]

7. Indrio, F.; Di Mauro, A.; Riezzo, G.; Civardi, E.; Intini, C.; Corvaglia, L.; Ballardini, E.; Bisceglia, M.; Cinquetti, M.; Brazzoduro, E.; et al. Prophylactic use of a probiotic in the prevention of colic, regurgitation, and functional constipation: A randomized clinical trial. JAMA Pediatr. 2014, 168, 228-233. [CrossRef] [PubMed]

8. Bellaiche, M.; Oozeer, R.; Gerardi-Temporel, G.; Faure, C.; Vandenplas, Y. Multiple functional gastrointestinal disorders are frequent in formula-fed infants and decrease their quality of life. Acta Paediatr. 2018, 107, 1276-1282. [CrossRef]

9. Levy, E.I.; Salvatore, S.; Vandenplas, Y.; de Winter, J.P. Prescription of acid inhibitors in infants: An addiction hard to break. Eur. J. Pediatr. 2020, 179, 1957-1961. [CrossRef]

10. Salvatore, S.; Abkari, A.; Cai, W.; Catto-Smith, A.; Cruchet, S.; Gottrand, F.; Hegar, B.; Lifschitz, C.; Ludwig, T.; Shah, N.; et al Review shows that parental reassurance and nutritional advice help to optimise the management of functional gastrointestinal disorders in infants. Acta Paediatr. 2018, 107, 1512-1520. [CrossRef]

11. Vandenplas, Y.; Steenhout, P.; Planoudis, Y.; Grathwohl, D.; Althera Study Group. Treating cow's milk protein allergy: A double-blind randomized trial comparing two extensively hydrolysed formulas with probiotics. Acta Paediatr. 2013, 102, 990-998. [CrossRef] [PubMed]

12. Vandenplas, Y.; Dupont, C.; Eigenmann, P.; Host, A.; Kuitunen, M.; Ribes-Koninckx, C.; Shah, N.; Shamir, R.; Staiano, A.; Szajewska, H.; et al. A workshop report on the development of the Cow's Milk-related Symptom Score awareness tool for young children. Acta Paediatr. 2015, 104, 334-339. [CrossRef] [PubMed]

13. Vandenplas, Y.; Salvatore, S.; Ribes-Koninckx, C.; Carvajal, E.; Szajewska, H.; Huysentruyt, K. The Cow Milk Symptom Score $\left(\right.$ CoMiSS $^{\mathrm{TM}}$ ) in presumed healthy infants. PLOS ONE 2018, 13, e0200603. [CrossRef]

14. Jung, C.; Beck, L.; Hanh, T.; Bellaiche, M. Quality of life of infants with functional gastrointestinal disorders: A large prospective observational study. Int. J. Child Health Nutr. 2017, 6, 62-69.

15. Schober, P.; Vetter, T.R. Repeated measures designs and analysis of longitudinal data: If at first you do not succeed-try, try again. Anesth. Analg. 2018, 127, 569-575. [CrossRef] [PubMed]

16. Lee, U.; Garcia, T.P.; Carroll, R.J.; Gilbreath, K.R.; Wu, G. Analysis of repeated measures data in nutrition research. Front. Biosci. 2019, 24, 1377-1389.

17. Huysentruyt, K.; Koppen, I.; Benninga, M.; Cattaert, T.; Cheng, J.; De Geyter, C.; Faure, C.; Gottrand, F.; Hegar, B.; Hojsak, I.; et al. The Brussels infant and toddler stool scale: A study on interobserver reliability. J. Pediatr. Gastroenterol. Nutr. 2019, 68, 207-213. [CrossRef] [PubMed]

18. Holscher, H.D.; Faust, K.L.; Czerkies, L.A.; Litov, R.; Ziegler, E.E.; Lessin, H.; Hatch, T.; Sun, S.; Tappenden, K.A. Effects of prebiotic-containing infant formula on gastrointestinal tolerance and fecal microbiota in a randomized controlled trial. J. Parenter. Enteral Nutr. 2012, 36 (Suppl. 1), 95S-105S. [CrossRef]

19. Costalos, C.; Kapiki, A.; Apostolou, M.; Papathoma, E. The effect of a prebiotic supplemented formula on growth and stool microbiology of term infants. Early Hum. Dev. 2008, 84, 45-49. [CrossRef]

20. Bakker-Zierikzee, A.M.; Alles, M.S.; Knol, J.; Kok, F.J.; Tolboom, J.J.; Bindels, J.G. Effects of infant formula containing a mixture of galacto- and fructo-oligosaccharides or viable Bifidobacterium animalis on the intestinal microflora during the first 4 months of life. Br. J. Nutr. 2005, 94, 783-790. [CrossRef]

21. Moro, G.; Minoli, I.; Mosca, M.; Fanaro, S.; Jelinek, J.; Stahl, B.; Boehm, G. Dosage-related bifidogenic effects of galacto- and fructooligosaccharides in formula-fed term infants. J. Pediatr. Gastroenterol. Nutr. 2002, 34, 291-295. [CrossRef] [PubMed]

22. Knol, J.; Boehm, G.; Lidestri, M.; Negretti, F.; Jelinek, J.; Agosti, M.; Stahl, B.; Marini, A.; Mosca, F. Increase of faecal bifidobacteria due to dietary oligosaccharides induces a reduction of clinically relevant pathogen germs in the faeces of formula-fed preterm infants. Acta Paediatr. Suppl. 2005, 94, 31-33. [CrossRef]

23. Bruzzese, E.; Volpicelli, M.; Squeglia, V.; Bruzzese, D.; Salvini, F.; Bisceglia, M.; Lionetti, P.; Cinquetti, M.; Iacono, G.; Amarri, S.; et al. A formula containing galacto- and fructo-oligosaccharides prevents intestinal and extra-intestinal infections: An observational study. Clin. Nutr. 2009, 28, 156-161. [CrossRef] 
24. Arslanoglu, S.; Moro, G.E.; Boehm, G. Early supplementation of prebiotic oligosaccharides protects formula-fed infants against infections during the first 6 months of life. J. Nutr. 2007, 137, 2420-2424. [CrossRef]

25. Scholtens, P.A.; Alliet, P.; Raes, M.; Alles, M.S.; Kroes, H.; Boehm, G.; Knippels, L.M.; Knol, J.; Vandenplas, Y. Fecal secretory immunoglobulin $\mathrm{A}$ is increased in healthy infants who receive a formula with short-chain galacto-oligosaccharides and long-chain fructo-oligosaccharide. Nutrition 2008, 138, 1141-1147. [CrossRef] [PubMed]

26. van Hoffen, E.; Ruiter, B.; Faber, J.; M’Rabet, L.; Knol, E.F.; Stahl, B.; Arslanoglu, S.; Moro, G.; Boehm, G.; Garssen, J. A specific mixture of short-chain galacto-oligosaccharides and long-chain fructo-oligosaccharides induces a beneficial immunoglobulin profile in infants at high risk for allergy. Allergy 2009, 64, 484-487. [CrossRef]

27. EFSA Panel on Dietetic Products, Nutrition and Allergies (NDA). Scientific Opinion on the essential composition of infant and follow-on formulae. EFSA J. 2014, 12, 3760. [CrossRef]

28. Commission Delegated Regulation ((EU) 2016/127). Available online: https://op.europa.eu/en/publication-detail/-/ publication/95d90c87-c97e-11e5-a4b5-01aa75ed71a1 (accessed on 18 September 2021).

29. Vandenplas, Y. The nutritional value of a whey hydrolysate formula compared with a whey-predominant formula in healthy infants. J. Pediatr. Gastroenterol. Nutr. 1993, 17, 92-96. [CrossRef]

30. Hauser, B.; Blecker, U.; Keymolen, K.; Suys, B.; Gerlo, E.; Vandenplas, Y. Plasma amino acid concentrations in term-born infants fed a whey predominant or a whey hydrolysate formula. J. Parenter. Enteral Nutr. 1997, 21, 27-30. [CrossRef]

31. Hauser, B.; Keymolen, K.; Blecker, U.; Suys, B.; Bougatef, A.; Loeb, H.; Vandenplas, Y. A comparative evaluation of whey hydrolysate and whey-predominant formulas. How well do infants accept and tolerate them? Clin. Pediatr. 1993, 32, $433-437$. [CrossRef]

32. Vandenplas, Y.; Al-Hussaini, B.; Al-Mannaei, K.; Al-Sunaid, A.; Helmi Ayesh, W.; El-Degeir, M.; El-Kabbany, N.; Hadda, J.; Hashmi, A.; Kreishan, F.; et al. Prevention of allergic sensitization and treatment of cow's milk protein allergy in early life: The Middle-East step-down consensus. Nutrients 2019, 11, 1444. [CrossRef]

33. Kiewiet, M.B.G.; van Esch, B.C.A.M.; Garssen, J.; Faas, M.M.; de Vos, P. Partially hydrolyzed whey proteins prevent clinical symptoms in a cow's milk allergy mouse model and enhance regulatory T and B cell frequencies. Mol. Nutr. Food Res. 2017, 61, 11. [CrossRef]

34. Giampietro, P.G.; Kjellman, N.I.; Oldaeus, G.; Wouters-Wesseling, W.; Businco, L. Hypoallergenicity of an extensively hydrolyzed whey formula. Pediatr. Allergy Immunol. 2001, 12, 83-86. [CrossRef]

35. Inuo, C.; Tanaka, K.; Nakajima, Y.; Yamawaki, K.; Matsubara, T.; Iwamoto, H.; Tsuge, I.; Urisu, A.; Kondo, Y. Tolerability of partially and extensively hydrolysed milk formulas in children with cow's milk allergy. Asia Pac. J. Clin. Nutr. 2019, $28,49-56$.

36. Francavilla, R.; Calasso, M.; Calace, L.; Siragusa, S.; Ndagijimana, M.; Vernocchi, P.; Brunetti, L.; Mancino, G.; Tedeschi, G.; Guerzoni, E.; et al. Plasma amino acid concentrations in term-born infants fed a whey predominant or a whey hydrolysate formula. Pediatr. Allergy Immunol. 2012, 23, 420-427. [CrossRef] [PubMed]

37. Abrams, S.A.; Griffin, I.J.; Davila, P.M. Calcium and zinc absorption from lactose-containing and lactose-free infant formulas. Am. J. Clin. Nutr. 2002, 76, 442-446. [CrossRef]

38. Lasekan, J.B.; Jacobs, J.; Reisinger, K.S.; Montalto, M.B.; Frantz, M.P.; Blatter, M.M. Lactose-free milk protein-based infant formula: Impact on growth and gastrointestinal tolerance in infants. Clin. Pediatr. 2011, 50, 330-337. [CrossRef] [PubMed]

39. Lasekan, J.B.; Baggs, G.E. Efficacy of soy-based formulas in alleviating gastrointestinal symptoms in infants with milk-based formula intolerance: A randomized clinical trial. Clin. Pediatr. 2021, 60, 184-192. [CrossRef] [PubMed]

40. Chao, H.C.; Vandenplas, Y. Therapeutic effect of Novalac-IT in infants with constipation. Nutrition 2007, 23, 469-473. [CrossRef]

41. Benninga, M.A.; MENA Infant Constipation Study Group; Vandenplas, Y. Magnesium-rich formula for functional constipation in infants: A randomized comparator-controlled study. Pediatr. Gastroenterol. Hepatol. Nutr. 2019, 22, 270-281. [CrossRef]

42. Infante, D.D.; Segarra, O.O.; Redecillas, S.S.; Alvarez, M.M.; Miserachs, M.M. Modification of stool's water content in constipated infants: Management with an adapted infant formula. Nutr. J. 2011, 10, 55. [CrossRef]

43. Xinias, I.; Analitis, A.; Mavroudi, A.; Roilides, I.; Lykogeorgou, M.; Delivoria, V.; Milingos, V.; Mylonopoulou, M.; Vandenplas, Y. A synbiotic infant formula with high magnesium content improves constipation and quality of life. Pediatr. Gastroenterol. Hepatol. Nutr. 2018, 21, 28-33. [CrossRef]

44. Savino, F.; Maccario, S.; Castagno, E.; Cresi, F.; Cavallo, F.; Dalmasso, P.; Fanaro, S.; Oggero, R.; Silvestro, L. Advances in the management of digestive problems during the first months of life. Acta Paediatr. Suppl. 2005, 94, 120-124. [CrossRef] [PubMed]

45. Savino, F.; Palumeri, E.; Castagno, E.; Cresi, F.; Dalmasso, P.; Cavallo, F.; Oggero, R. Reduction of crying episodes owing to infantile colic: A randomized controlled study on the efficacy of a new infant formula. Eur. J. Clin. Nutr. 2006, 60, 1304-1310. [CrossRef] [PubMed]

46. Hyams, J.S.; Treem, W.R.; Etienne, N.L.; Weinerman, H.; MacGilpin, D.; Hine, P. Effect of infant formula on stool characteristics of young infants. Pediatrics 1995, 95, 50-54. [PubMed]

47. Scholtens, P.A.; Goossens, D.A.; Staiano, A. Stool characteristics of infants receiving short-chain galacto-oligosaccharides and long-chain fructo-oligosaccharides: A review. World J. Gastroenterol. 2014, 20, 13446-13452. [CrossRef] [PubMed]

48. Bongers, M.E.; de Lorijn, F.; Reitsma, J.B.; Groeneweg, M.; Taminiau, J.A.; Benninga, M.A. The clinical effect of a new infant formula in term infants with constipation: A double-blind, randomized cross-over trial. Nutr. J. 2007, 6, 8. [CrossRef] [PubMed] 
49. Vivatvakin, B.; Mahayosnond, A.; Theamboonlers, A.; Steenhout, P.G.; Conus, N.J. Effect of a whey-predominant starter formula containing LCPUFAs and oligosaccharides (FOS/GOS) on gastrointestinal comfort in infants. Asia Pac. J. Clin. Nutr. 2010, 19, 473-480.

50. Coccorullo, P.; Strisciuglio, C.; Martinelli, M.; Miele, E.; Greco, L.; Staiano, A. Lactobacillus reuteri (DSM 17938) in infants with functional chronic constipation: A double-blind, randomized, placebo-controlled study. J. Pediatr. 2010, 157, 598-602. [CrossRef]

51. de Weerth, C.; Fuentes, S.; de Vos, W.M. Crying in infants: On the possible role of intestinal microbiota in the development of colic. Gut Microbes 2013, 4, 416-421. [CrossRef]

52. Vandenplas, Y.; Ludwig, T.; Bouritius, H.; Alliet, P.; Forde, D.; Peeters, S.; Huet, F.; Hourihane, J. Randomised controlled trial demonstrates that fermented infant formula with short-chain galacto-oligosaccharides and long-chain fructo-oligosaccharides reduces the incidence of infantile colic. Acta Paediatr. 2017, 106, 1150-1158. [CrossRef] [PubMed]

53. Dryl, R.; Szajewska, H. Probiotics for management of infantile colic: A systematic review of randomized controlled trials. Arch. Med. Sci. 2018, 14, 1137-1143. [CrossRef] [PubMed]

54. Gutiérrez-Castrellón, P.; Indrio, F.; Bolio-Galvis, A.; Jiménez-Gutiérrez, C.; Jimenez-Escobar, I.; López-Velázquez, G. Efficacy of Lactobacillus reuteri DSM 17938 for infantile colic: Systematic review with network meta-analysis. Medicine 2017, 96, e9375. [CrossRef] [PubMed]

55. Salvatore, S.; Savino, F.; Singendonk, M.; Tabbers, M.; Benninga, M.A.; Staiano, A.; Vandenplas, Y. Thickened infant formula: What to know? Nutrition 2018, 49, 51-56. [CrossRef]

56. Billeaud, C.; Guillet, J.; Sandler, B. Gastric emptying in infants with or without gastro-oesophageal reflux according to the type of milk. Eur. J. Clin. Nutr. 1990, 44, 577-583.

57. Indrio, F.; Riezzo, G.; Giordano, P.; Ficarella, M.; Miolla, M.P.; Martini, S.; Corvaglia, L.; Francavilla, R. Effect of a partially hydrolysed whey infant formula supplemented with starch and Lactobacillus reuteri DSM 17938 on regurgitation and gastric motility. Nutrients 2017, 9, 1181. [CrossRef] [PubMed]

58. Chevallier, B.; Fournier, V.; Logre, B.; Beck, L.; Ceccato, F.; Hui Bon Hoa, G.; Lachambre, E.; Van Egroo, L.D.; Sznajder, M. Value of a new thickened formula in infants with regurgitations. Arch. Pediatr. 2009, 16, 343-352. [CrossRef]

59. Gatcheco, F.; Vitug Sales, M.I.; Battad, G.; Tan, M.; Gloria, M.C.D.; Kudla, U.; Muhardi, L. Nutritional management of GER among infants in the Philippines: Insights form real world evidence. Int. J. Clin. Pediatr. 2019, 8, 1-7. [CrossRef]

60. Bellaiche, M.; Ludwig, T.; Arciszewska, M.; Bongers, A.; Gomes, C.; Świat, A.; Dakhlia, F.; Piollet, A.; Oozeer, R.; Vandenplas, Y. Safety and tolerance of a novel anti-regurgitation formula: A double-blind, randomised, controlled trial. J. Pediatr. Gastroenterol. Nutr. 2021, in press. [CrossRef]

61. Fatheree, N.Y.; Liu, Y.; Taylor, C.M.; Hoang, T.K.; Cai, C.; Rahbar, M.H.; Hessabi, M.; Ferris, M.; McMurtry, V.; Wong, C.; et al. Lactobacillus reuteri for infants with colic: A double-blind, placebo-controlled, randomized clinical trial. J. Pediatr. 2017, 191, 170-178.e2. [CrossRef]

62. Turco, R.; Russo, M.; Bruzzese, D.; Staiano, A. Efficacy of a partially hydrolysed formula, with reduced lactose content and with Lactobacillus reuteri DSM 17938 in infant colic: A double blind, randomised clinical trial. Clin. Nutr. 2021, 40, 412-419. [CrossRef] [PubMed]

63. Verduci, E.; Giannì, M.L.; Vizzari, G.; Vizzuso, S.; Cerasani, J.; Mosca, F.; Zuccotti, G.V. The triad mother-breast milk-infant as predictor of future health: A narrative review. Nutrients 2021, 13, 486. [CrossRef] [PubMed]

64. van Esch, B.C.A.M.; Porbahaie, M.; Abbring, S.; Garssen, J.; Potaczek, D.P.; Savelkoul, H.F.J.; van Neerven, R.J.J. The impact of milk and its components on epigenetic programming of immune function in early life and beyond: Implications for allergy and asthma. Front. Immunol. 2020, 11, 2141. [CrossRef] [PubMed]

65. Acevedo, N.; Alhamwe, B.A.; Caraballo, L.; Ding, M.; Ferrante, A.; Garn, H.; Garssen, J.; Hii, C.S.; Irvine, J.; Llinás-Caballero, K.; et al. Perinatal and early-life nutrition, epigenetics, and allergy. Nutrients 2021, 13, 724. [CrossRef] [PubMed] 